Int. J. Odontostomat.,

10(2):283-286, 2016.

\title{
Candida spp. in Complete Dentures of Institutionalized Elderly Individuals
}

\author{
Candida spp. en Prótesis Dentales Totales de Personas Mayores Institucionalizadas
}

\begin{abstract}
Robson de Sousa Ferreira*; Tássio Luiz da Silva Freitas*; Adelmar Pereira da Silva-Neto*; Naiara de Farias Rosa**; Josie Haydée Lima Ferreira ${ }^{* * *}$ \& Glauber Campos Vale ${ }^{* * *}$
\end{abstract}

FERREIRA, R. S.; FREITAS, T. L. S.; SILVA-NETO, A. P.; ROSA, N. F.; FERREIRA, J. H. L. \& VALE, G. C. Candida spp. in complete dentures of institutionalized elderly individuals. Int. J. Odontostomat., 10(2):283-286, 2016.

ABSTRACT: The objective of this study was to evaluate the prevalence of Candida spp. in complete dentures of institucionalized elderly, aged 60 or more, in a city of northeast of Brazil. A survey was conducted of the health profile and quantification of Candida spp. from isolation in Sabouraud agar. Our results showed that from 181 institutionalized elderlies, only 17 (66-84 years) met the inclusion criteria. $47.1 \%$ were totally dependent, and $58.8 \%$ needed help with hygiene. The most commonly used drugs were antihypertensive. The results showed a high prevalence of Candida spp. (64.5\%) in the dentures of institutionalized elderly and this may be a reflection of poor oral hygiene.

KEY WORDS: elderly, Candida, oral hygiene.

\section{INTRODUCTION}

The normal oral flora comprises a diverse range of organisms including eubacteria, archaebacteria, fungi, mycoplasma and protozoa (Samaranayake, 2006). Among these microorganisms, fungi are classified as eukaryotes, fungi belonging to genus Candida the most important for dentistry. Species of this genus can be collected from up to one third of the healthy individuals' mouth and are considered residents of the normal oral and gastrointestinal tract flora (Krishnan, 2012).

Human infections caused by Candida albicans and other species of the genus range from commonly found oral candidiasis from potentially fatal systemic infections in patients suppressed by other diseases (Arkell \& Shinnick, 2003). Denture stomatitis (DS) is characterized by a common inflammatory lesion in the palatal mucosa of denture users, showing an erythema with variable intensity and length. DS is multifactorial and involves predisposing factors such as the stability of the denture, hygiene and sustainable use, and systemic factors, such as immune and endocrine diseases, nutritional deficiency, and some medications, including steroids, antibiotics and immunosuppressants (Salerno et al., 2011).

Among local factors, the reduced salivary flow rate and change in the composition of saliva are considered the most important for the proliferation of Candida in the oral cavity and from candidiasis development (Parvinen \& Larmas, 1981). An association between denture stomatitis and Candida spp, especially C. albicans, has been reported. The C. albicans species produces biofilm in mucosal surfaces, driven by changes in host immunity or own oral microflora (Budtz-Jörgensen, 1978). An increased risk to oral disease is a possibility in vulnerable older people since disability and restrictions associated with these conditions may impair the ability to perform self-care oral hygiene (Farah et al., 2010) or restrict access to dental care (Padilha et al., 2007).

\footnotetext{
Postgraduate Program in Dentistry, Federal University of Piauí, Campus Universitário Ministro Petrônio Portella, Teresina, Brazil. ** Dentistry Course of Federal University of Piauí, Campus Universitário Ministro Petrônio Portella, Teresina, Brazil.

*** Microbiology and Parasitology Department, Federal University of Piauí, Campus Universitário Ministro Petrônio Portella, Teresina, Brazil.

Restorative Dentistry Department, Federal University of Piauí, Campus Universitário Ministro Petrônio Portella, Teresina, Brazil.
} 
In Brazil, the elderly population living in public or private shelters is increasing every year. This population frequently has chronic diseases and impaired functional capacity, making it more susceptible to dental problems. However, attention to oral health programs targeted to the elderly are still rare. In general, epidemiological data that characterize the health of institutionalized elderlies are virtually non-existent (Avlund et al., 2001). Thus, it is important to study the association of the use of dentures and prevalence of Candida spp in institutionalized elderlies in the city of Teresina - PI in order to redirect the oral health policies for this population.

\section{MATERIAL AND METHOD}

Ethical aspects. This study was approved by the Ethics Comittee of the Federal University of Piauí under the protocol 856.464 , following the guidelines of the Helsinki Declaration.

Population study. A cross-sectional study was carried out with a quantitative approach in the elderly population aged 60 and over, institutionalized in shelters in the city of Teresina, Piauí, Brazil. The following inclusion criteria were used: being over 60 , wear complete maxillary dentures for at least six months and have good general health. The first part of the study was the survey of the complete denture users profilethrough the application of a structured socioeconomic questionnaire (Table I).

Microbiological procedures. The second part of the survey, consisted in microbiological evaluation. Collection of biological material was carried out by vigorous rubbing with a sterile cotton swab on all surfaces of the prosthesis for $1 \mathrm{~min}$ and stored in a tube containing $1 \mathrm{~mL}$ of sterile saline, identified with the name of the patient, until processing. Samples were transported under refrigeration and processed within two hours after collection.

Three dilutions were performed (10-1 to $10-3)$ from the original suspension in the tube used for collection and a volume of $50 \mu \mathrm{L}$ was inoculated on the surface of the medium SDA (Sabouraud Dextrose Agar, Himedia Labs, Mumbai, India) with chloramphenicol after stirring for $1 \mathrm{~min}$ to oust the swab cells. The plating was performed in the surface of Petri dishes through the spread plate technique with the aid of Drigalski handle. The plates were incubated at $37^{\circ} \mathrm{C}$ for $24-48 \mathrm{~h}$ under aerobic conditions, for subsequent counting. Tests were performed in duplicat and the results were described by the average CFU/mL of each patient.

To evaluate the prevalence of Candida spp., total mesophilic count was performed. In this case, the samples were plated on agar sheep blood (Tryptone Soy Agar, Himedia Labs, Mumbai, India) using the same methodology used for the SDA media. The plates were incubated at $37^{\circ} \mathrm{C}$ for $24-48 \mathrm{~h}$ under conditions of aerobic and anaerobic conditions for subsequent counting. Tests were performed in duplicate and the results were described by the average $\mathrm{CFU} / \mathrm{mL}$ of each patient.

Data Analysis. All data were statistically analyzed using Microsoft Excel 2013 for Windows 8.0. Descriptive statistical analyses (absolute and relative frequencies) were performed in this study.

\section{RESULTS}

Four shelters in the city of Teresina - PI were searched and from the total institutionalized elderly (181), only 17 (9.4\%) met the study criteria and two of these shelters were visited. Some demographic characteristics of the individuals and other factors of interest are described in Table I.

The age of the elderly ranged from 66-84 years, mean age $75 \pm 6.9$ years. Most patients $(47.1 \%)$ had no income; $41.2 \%$ had an income of a minimum wage (corresponding to retirement) and $11.7 \%$ had between two and five minimum wages. As for the state of dependency, 3 elderly subjects $(17.6 \%)$ were independent, 6 (35.3\%) partially dependent and 8 (47.1 $\%)$ totally dependent.

Table I. Description of the patients' demographic characteristics and other factors.

\begin{tabular}{lccccc}
\hline & \multicolumn{2}{c}{ Demographic characteristics } & \multicolumn{2}{c}{ Other factors } \\
\cline { 2 - 6 } & $\begin{array}{c}\text { Mean age } \\
\text { (years old) }\end{array}$ & Sex & $\begin{array}{c}\text { Smoking } \\
\text { habits }\end{array}$ & $\begin{array}{c}\text { Clinical palate } \\
\text { conditions }\end{array}$ & $\begin{array}{c}\text { Assistance for } \\
\text { denture hygiene (\%) }\end{array}$ \\
\hline Patients $(\mathrm{n}=17)$ & 75.0 & $\begin{array}{c}70.6 \% \text { female } \\
29.4 \% \text { male }\end{array}$ & $\begin{array}{c}\text { Actually none } \\
(47.1 \% \text { ex-smokers) }\end{array}$ & $\begin{array}{c}\text { Healthy } \\
\text { palate tissue }\end{array}$ & 58.8 \\
& & &
\end{tabular}


The 17 elederly analyzed reported at least one disease at present or in the past. The most common reports were hypertension, neurological and psychiatric disorders, gastrointestinal problems, heart disease and diabetes. They all reported using medication at the time, and the nurses of the shelters reported the medication used and frequency, according to medical records and daily monitoring. According to these professionals, all used more than one medication, and recorded the use of 46 different drugs by the elderly.

The most frequently used medications were antihypertensives (14 reports), diuretics (first report), nonsteroidal anti-inflammatory drug (6 reports), oral hypoglycemic agents ( 3 cases), treatment of Alzheimer's disease (4 reports), antidepressants (3 reports), vitamin supplements (2 reports), antipsychotics (5 reports), treatment of gastrointestinal disorders (5 reports), digitalis (1 report), treatment of Parkinson's disease (2 reports), anxiolytics (5 reports), treatment of other vascular changes (2 reports), analgesics (2 reports), dermatitis treatment (1 report) and calcium replacement (1 report).

Candida spp. quantification was determined in dental prostheses. After the incubation time, there was the count of the colonies on the plates. The frequency of microorganisms identified is shown in Table II.

Table II. Prevalence of microorganisms identified in the upper dentures institutionalized elderly.

\begin{tabular}{lcc}
\hline \multirow{2}{*}{ Microorganisms } & \multicolumn{2}{c}{ Dentures (total= 17) } \\
\cline { 2 - 3 } & Number & \% \\
\hline Candida spp. & 11 & 64.5 \\
Total microorganisms & 17 & 100 \\
\hline
\end{tabular}

\section{DISCUSSION}

The fungi of the genus Candida establish a commensal relationship with the host. Around $60 \%$ of denture users have some inflammation caused by fungi of the genus Candida. According to available scientific evidence, the presence of the etiological agent alone is not enough to produce clinically injuries, requiring at least superficial tissue penetration and others predisposing factors (Figueiral et al., 2007; Salerno et al.).

Most problems related to the use of dentures occur due to the lack of maintenance and instruction on their use (da Silva et al., 2011). In the surveyed shelters, caregivers reported that the limited use of dentures for institutionalized elderly is due to maladjustment of those over time. Most of them failed to make use of dentures for lack of maintenance due to low dental assistence, causing loss of retention, or the presence of problems related to inflammatory processes associated with dentures. Failure in dental monitoring can result in illfitting dentures that cause discomfort, pain and injury that may favor infection (Gosavi et al., 2013).

The age of the elderly ranged $66-84$ years $(75 \pm 6.9$, mean \pm SD). The great general problem that affects oral health in old age are disabling (advanced Parkinson's disease, motor disorders, arthritis, Alzheimer's and depression) and metabolic diseases. Thus, it is often necessary to reorient individually with respect to hygiene and if possible, make adaptations to facilitate its execution and use preventive and therapeutic substances (Evren et al., 2011).

The pharmacological activity of many drugs can have a suppressive effect on normal gastrointestinal and oral bacterial flora and naturally maintains the Candida population in check. This means that there may be overgrowth as a result of such effects of drugs. The broad-spectrum antibiotics group predisposes to Candida infection by this mode of action (Zegarelli, 1993). Most general health condition in this study were vascular changes ( $94.1 \%$ of subjects), where the most commonly used drugs were antihypertensive. $58.8 \%$ of participants needed aid for cleaning teeth and/or dentures. Thus, the training of elderly caregivers is considered important to perform oral hygiene of patients who need help, ensuring a satisfactory care to those who can no longer perform them properly (Vasan et al., 2001). Related information should also be extended to those who reported being self-sufficient.

According to Salerno et al., C. albicans is the main species involved in inflammatory processes associated with the use of dental prosthesis and this is related to the ability to maintain its viability in hard and soft tissues through formation of biofilms that guarantee it adhesion. The presence of dentures increases the prevalence and incidence of Candida colony forming units (CFU's), which means that there is greater probability of occurrence of some forms of oral candidiasis (Atchison \& Dolan, 1990; Reichart et al., 2000). As the prevalence of various Candida species, the $C$. albicans is the most commonly isolated, with amounts from about $30 \%$ (Ramage et al., 2004) to approximately $80 \%$ (Webb et al., 2005). Results of the measurement obtained from the conventional isolating of Candida spp. in SDA with chloramphenicol 
confirmed $64.5 \%$ of the patients positive for the presence of the fungus (Table II).

In conclusion, high prevalence of Candida spp. was observed in the complete dentures of institutionalized elderly. The cleaning of the denture was performed poorly, with this fact related to the increased prevalence of Candida spp. in the oral cavity.

FERREIRA, R. S.; FREITAS, T. L. S.; SILVA-NETO, A. P.; ROSA, N. F.; FERREIRA, J. H. L. \& VALE, G. C. Candida spp. en prótesis dentales totales de personas mayores institucionalizadas. Int. J. Odontostomat., 10(2):283-286, 2016.

RESUMEN: El objetivo fue asociar el uso de prótesis dentales totales y la prevalencia de Candida spp. en ancianos institucionalizados con 60 o más años de edad, en una ciudad del Nordeste de Brasil. Se llevó a cabo un estudio del perfil de salud y cuantificación de Candida spp. por aislamiento con agar Sabouraud. A partir de 181 ancianos institucionalizados, sólo 17 (66-84 años) cumplieron los criterios de inclusión. 47,1 \% eran totalmente dependientes y $58,8 \%$ necesitó ayuda con la higiene. Los fármacos más utilizados fueron antihipertensivos. Los resultados mostraron una alta prevalencia de Candida spp. (64,5 \%) en las prótesis dentales totales de los ancianos institucionalizados y esto tal vez sea un reflejo de la deficiente higiene oral.

PALABRAS CLAVE: ancianos, Candida, higiene oral.

\section{REFERENCES}

Arkell, S. \& Shinnick, A. Update on oral candidosis. Nurs. Times, 99(48):52-3, 2003

Atchison, K. A. \& Dolan, T. A. Development of the geriatric oral health assessment index. J. Dent. Educ., 54(11):680-7, 1990.

Avlund, K.; Holm-Pedersen, P. \& Schroll, M. Functional ability and oral health among older people: a longitudinal study from age 75 to 80. J. Am. Geriatr. Soc., 49(7):954-62, 2001.

Budtz-Jörgensen, E. Clinical aspects of Candida infection in denture wearers. J. Am. Dent. Assoc., 96(3):474-9, 1978.

da Silva, H. F.; Martins-Filho, P. R. \& Piva, M. R. Denture-related oral mucosal lesions among farmers in a semi-arid Northeastern Region of Brazil. Med. Oral Patol. Oral Cir. Bucal, 16(6):e740-4, 2011.

Evren, B. A.; Uludamar, A.; Iseri, U. \& Ozkan, Y. K. The association between socioeconomic status, oral hygiene practice, denture stomatitis and oral status in elderly people living different residential homes. Arch. Gerontol. Geriatr., 53(3):252-7, 2011.

Farah, C. S.; Lynch, N. \& McCullough, M. J. Oral fungal infections: an update for the general practitioner. Aust. Dent. J., 55(Suppl. 1):4854, 2010.
Figueiral, M. H.; Azul, A.; Pinto, E.; Fonseca, P. A.; Branco, F. M. \& Scully, C. Denture-related stomatitis: identification of aetiological and predisposing factors - a large cohort. J. Oral Rehabil., 34(6):448-55, 2007

Gosavi, S. S.; Ghanchi, M.; Malik, S. A. \& Sanyal, P. A survey of complete denture patients experiencing difficulties with their prostheses. J. Contemp. Dent. Pract., 14(3):524-7, 2013.

Krishnan, P. A. Fungal infections of the oral mucosa. Indian J. Dent. Res., 23(5):650-9, 2012.

Padilha, D. M.; Hugo, F. N.; Hilgert, J. B. \& Dal Moro, R. G. Hand function and oral hygiene in older institutionalized Brazilians. $J$. Am. Geriatr. Soc., 55(9):1333-8, 2007.

Parvinen, T. \& Larmas, M. The relation of stimulated salivary flow rate and $\mathrm{pH}$ to Lactobacillus and yeast concentrations in saliva. J. Dent. Res., 60(12):1929-35, 1981.

Ramage, G.; Tomsett, K.; Wickes, B. L.; López-Ribot, J. L. \& Redding, S. W. Denture stomatitis: a role for Candida biofilms. Oral Surg. Oral Med. Oral Pathol. Oral Radiol. Endod., 98(1):53-9, 2004.

Reichart, P. A.; Samaranayake, L. P. \& Philipsen, H. P. Pathology and clinical correlates in oral candidiasis and its variants: a review. Oral Dis., 6(2):85-91, 2000.

Salerno, C.; Pascale, M.; Contaldo, M.; Esposito, V.; Busciolano, M.; Milillo, L.; Guida, A.; Petruzzi, M. \& Serpico, R. Candida-associated denture stomatitis. Med. Oral Patol. Oral Cir. Bucal, 16(2):e13943, 2011.

Samaranayake, L. P. Essential Microbiology for Dentistry. $3^{\text {rd }}$ ed. Edinburgh, Churchill Livingstone Elsevier, 2006. pp.62-4.

Vasan, R. S.; Larson, M. G.; Leip, E. P.; Evans, J. C.; O'Donnell, C. J.; Kannel, W. B. \& Levy, D. Impact of high-normal blood pressure on the risk of cardiovascular disease. N. Engl. J. Med., 345(18):1291-7, 2001.

Webb, B. C.; Thomas, C. J. \& Whittle, T. A 2-year study of Candidaassociated denture stomatitis treatment in aged care subjects. Gerodontology, 22(3):168-76, 2005.

Zegarelli, D. J. Fungal infections of the oral cavity. Otolaryngol. Clin. North Am., 26(6):1069-89, 1993.

Correspondence to:

Gláuber Campos Vale

DDS, MSc, PhD, Prof. Adjunto

Dep. de Odontologia Restauradora

Universidade Federal do Piauí - UFPI

Campus Universitário Ministro Petrônio Portella

SG10, 64049-550

Teresina (PI)

BRAZIL

Email: valeglauber80@gmail.com

Received: 27-05-2016

Accepted: 18-07-2016 